\title{
Ranking Structure Instituted in Duke Libraries
}

On May 28, 1974, the Duke University Librarians' Assembly formally approved the proposals of the Committee on Professional Staff Structure defining a ranking structure for Duke librarians, with mechanisms for implementation and for increased staff participation in library governance. The four documents which comprise the committee's report ${ }^{*}$ grew out of a two-year study of developments in other university libraries, as well as extensive discussions with members of the Duke staff, library and university administrations, and knowledgeable members of the profession outside the Duke community. After receiving the endorsement of the assembly and the library administration, the documents were submitted by university librarian Benjamin E. Powell to the provost for his approval, with implementation beginning in July.

Basic to the philosophy of the new structure is the idea that rank adheres to the individual rather than the position. The result is a ranking of persons rather than a classification of positions. Thus nonadministrative, as well as administrative, merit and accomplishment can be recognized and rewarded.

Under the new structure there will be four ranks whose titles are, in ascending order, assistant librarian, senior assistant librarian, associate librarian, and librarian. Each librarian will have a position title and a ranking title, e.g., subject cataloger with rank of senior assistant librarian. All librarians who do not hold faculty rank will have a librarian rank. To avoid confusion with the ranking titles, the upper admin-

- Criteria for Appointment of Professional Librarians, Ranking Structure for Duke Librarians, Committee on Appointment and Promotion, and Duke University Librarians' Assembly.

ACRL Membership

August 31, 1974

August 31, 1973

12,633

August 31, 1972

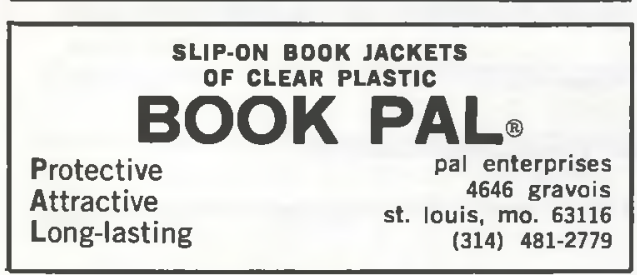

istrative titles will be designated assistant university librarian, associate university librarian, and university librarian. Broadly stated, the criteria for promotion in rank are a high quality of performance in the area of the librarian's responsibility; professional and academic achievement; and dedication to librarianship and participation in larger university affairs.

In accordance with the bylaws of the university, appointments and promotions of professional librarians are made by the provost, with the approval of the president, upon recommendation by the university librarian, the librarian of the School of Law, and the director of the Medical Center Library. In the Perkins system (all Duke libraries except Law and Medicine), ranking and promotion will be determined by a combination of peer evaluation and administrative/supervisory evaluation. Since July 1972 an ad hoc Credentials Committee has reviewed and certified the credentials of new professional appointees. More recently an ad hoc Ranking Committee has reviewed the vitas and evaluations of the entire professional staff and made recommendations to the university librarian on the initial ranks, which became effective in July 1974. In October a Committee on Appointment and Promotion, selected by the Librarians' Assembly, will take the place of the ad hoc committees, combining both functions in a single peer review committee. Final authority within the library for appointment and promotion decisions continues to rest with the university librarian.

The Medical Center librarians have adopted the ranking structure and will participate in all aspects of the assembly except the Committee on Appointment and Promotion. Ranks will be administratively determined within that system. The Law librarians have decided at the present time to participate in neither the ranking structure nor the assembly.

Inaugurated in December 1973, the Librarians' Assembly with its three standing committees-Executive, Appointment and Promotion, and Professional Affairs-will help to implement the structure and provide an additional means of staff participation in library governance and university affairs. Through its committees or acting as a whole, it will channel staff input on professional appointments and promotions, encourage continuing education and professional growth, recommend policies and procedures concerning the libraries, and assist in maintaining high standards of librarianship. 